\title{
SOIL AND PERMAFROST IN THE ROSS SEA REGION OF ANTARCTICA: STABLE OR DYNAMIC?
}

\author{
M.R. BALKS*, T.A. O’NEILL
}

University of Waikato, New Zealand.

\begin{abstract}
Soils in the Ross Sea Region of Antarctica generally comprise a surface desert pavement and a seasonally thawed active layer over permafrost. Most soils are formed on regolith such as glacial till or colluvium. Mean annual air temperatures range from $-18^{\circ} \mathrm{C}$ to $-24^{\circ} \mathrm{C}$ with low precipitation. The active layer ranges in depth from minimal in higher altitude, colder sites, to near $1 \mathrm{~m}$ deep at warmer coastal sites in the northern part of the region. Underlying permafrost may be ice-cemented, or dry with no ice cement. In some areas ice-cored moraine occurs where there is a large body of ice within the subsoil permafrost. Two examples of active gully/fan -forming events, one at Cape Evans and one at Lake Vanda are described. At the Cape Evans event water from a small lake thawed and came into contact with the ice in the underlying patterned ground ice-wedge causing the ice-wedge to melt and extensive gully erosion to occur. A fan-building event near Lake Vanda in the Wright Valley resulted in erosive and depositional features covering a horizontal distance of about $3 \mathrm{~km}$ and an altitudinal range of about $1400 \mathrm{~m}$. Such occasional events, can be attributed to warmer than average summers, and were first described in the Ross Sea Region in the 1970s. The Cape Evans and Lake Vanda events are examples of active, rapid, landscape processes and show that landscapes are not as static as is often assumed.
\end{abstract}

Suelo y permafrost en la región del Mar de Ross de la Antártida: ¿estables o dinámicos?

RESUMEN. Los suelos en la región del Mar de Ross en la Antártida comprenden generalmente un pavimento superficial desértico y un nivel activo que se descongela estacionalmente por encima del permafrost. La mayoría de los suelos están formados sobre un regolito de tipo till glaciar o coluvión. Las temperaturas medias anuales oscilan entre $-18^{\circ} \mathrm{C}$ y $-24^{\circ} \mathrm{C}$, con una escasa precipitación. El nivel activo oscila desde valores mínimos en áreas de elevada altitud y sitios fríos, hasta $1 \mathrm{~m}$ de profundidad en sitios costeros más templados en la parte norte de la región. El permafrost subyacente puede estar cementado por el hielo, o seco, sin cemento helado. En algunas áreas hay morrenas con hielo interno en las que existe un gran cuerpo de hielo dentro del permafrost. Se describen dos ejemplos de formación de cárcavas y conos de deyección, uno en el Cabo Evans y el otro en el Lago Vanda. 
En el Cabo Evans, el agua de un pequeño lago se descongeló y se puso en contacto con el hielo en cuñas de hielo de suelos ordenados, causando la fusión de las cuñas de hielo y extensiva erosión por cárcavas. Un evento de construcción de cono de deyección cerca del Lago Vanda en el Valle Wright dio lugar a rasgos erosivos y deposicionales que cubrieron una distancia horizontal de unos $3 \mathrm{~km}$ en una escala altitudinal de unos $1400 \mathrm{~m}$. Estos eventos ocasionales pueden atribuirse a veranos más cálidos que la media, y fueron descritos por primera vez en la región del Mar de Ross en la década de 1970. Los eventos del Cabo Evans y del Lago Vanda son ejemplos de procesos activos y rápidos en el paisaje, y muestran que éste último no es estático como frecuentemente se ha asumido.

Key words: cryosol, gelisol, soil temperature, geomorphic processes.

Palabras clave: criosol, suelo helado, temperatura del suelo, procesos geomórficos.

Received 17 December 2015

Accepted 8 February 2016

*Corresponding author: University of Waikato, Private Bag 3105, Hamilton, New Zealand, 3240. E-mail: m.balks@ waikato.ac.nz

\section{Introduction}

An understanding of Antarctic soils and the underlying permafrost is important to predict impacts of human activities or environmental changes, such as warming, on the soil and on geomorphological processes. The McMurdo Dry Valleys (MDVs) fall within the Ross Sea Region which lies directly south of New Zealand and stretches from latitude $70^{\circ} \mathrm{S}$ to $90^{\circ} \mathrm{S}$ and from longitude $150^{\circ} \mathrm{E}$ through $180^{\circ}$ to $150^{\circ} \mathrm{W}$ (Fig. 1). Ice-free areas with soil development occur in small pockets along the coastal margins and in the MDVs as well as in isolated areas of the Trans Antarctic Mountains further south. Soils in the MDVs and the wider Ross Sea Region are the most extensive (about $6700 \mathrm{~km}^{2}$, Bockheim, 2015a), and most studied area of Antarctic soils (Campbell and Claridge, 1987; Campbell et al., 1998a; Bockheim and McLeod, 2015). They are often described as "cold desert" soils, reflecting their cold, arid, climate. As they contain permafrost and are seasonally frozen to the ground surface the soils in the Ross Sea Region are classified as Gelisols (Soil Survey Staff, 2014) or Cryosols (IUSS Working Group WRB, 2014). Underlying permafrost is less well described as, particularly where ice-cemented permafrost occurs, it is difficult to access. The soils and landscapes of the Ross Sea Region are generally thought of as particularly stable (Denton et al., 1993), with soil development progressing only slowly (Campbell and Claridge, 1987), however in this paper we explore some examples of rapid, active, landscape processes occurring occasionally.

The objectives of this paper are: (1) to review the information describing soils and the underlying permafrost in the Ross Sea Region, with a particular focus on the MDVs and soil physical properties; (2) to describe two events where active landscape 
processes have occurred in the last decade as a result of interaction between surface events and the underlying permafrost; and (3) to discuss the possible response of permafrost-influenced landscapes to future physical environmental changes, both natural and human-induced.

\section{Soil properties}

\subsection{Influence of soil forming factors}

The soil forming factors of parent material, climate, time, and topography are all important in influencing soil development in the MDVs (Balks et al., 2013). The impacts of organisms are limited to a few isolated sites in coastal areas of the Ross Sea Region, such as penguin rookeries and areas where summer meltwater flows support moss growth (e.g. Cape Hallett, Hofstee et al., 2006).

Within the MDVs the basement rocks are mainly Precambrian to Ordovician schists, gneiss, marble, and granites (Isaac et al., 1996). These are overlain by a range of rock types dominated in many areas by Devonian to Triassic quartz sandstones of the Beacon Supergroup which are intruded by the Jurassic Ferrar dolerites (Isaac et al., 1996). Ross Island comprises mainly basaltic materials. The soils strongly reflect the parent rocks from which they are formed due to the relatively limited weathering that occurs (Campbell and Claridge, 1987). Soils formed on bedrock are generally shallow (Lithic Haplorthels) as it is rare in the Ross Sea Region for weathering to penetrate far into bedrock. Most of the soils studied or described are formed on regolith such as glacial till or colluvium. Soils on regolith often form from a range of lithologies as rocks have been mixed during transport and deposition.

Climate influences the rate of soil-forming processes to such an extent that other factors such as time or parent material are often subordinate (Campbell and Claridge, 1987). The MDVs are ice-free because evaporation generally exceeds precipitation in areas where soils are exposed. The cold temperatures and lack of liquid water restrict the degree and rate of chemical weathering thus the soils are dominated by gravelly sand materials formed by physical weathering of parent rocks. Mean annual air temperatures range from $-18^{\circ} \mathrm{C}$ at Marble Point, near the coast, through $-20^{\circ} \mathrm{C}$ on the floor of the Wright Valley, to $-24^{\circ} \mathrm{C}$ on Mt Fleming at the head of the Wright Valley at $1700 \mathrm{~m}$ altitude (Seybold et al., 2009; Goddard, 2013). In the MDVs snowfall, and rare rainfall, occurs mainly in summer. On the mid-valley floors precipitation is lowest with a mean annual precipitation of $45 \mathrm{~mm}$ recorded at Vanda Station over two years (Campbell and Claridge, 1987). Snowfall is higher at the eastern and western ends of the valleys and at higher altitudes. In summer snowfall often sublimates within an hour or two of falling on the valley floors, and within a day or two at higher altitudes. Precipitation is higher in coastal areas with snow accumulating over winter, and following summer snowfall events. The subsequent melting provides limited moisture to the soil. 


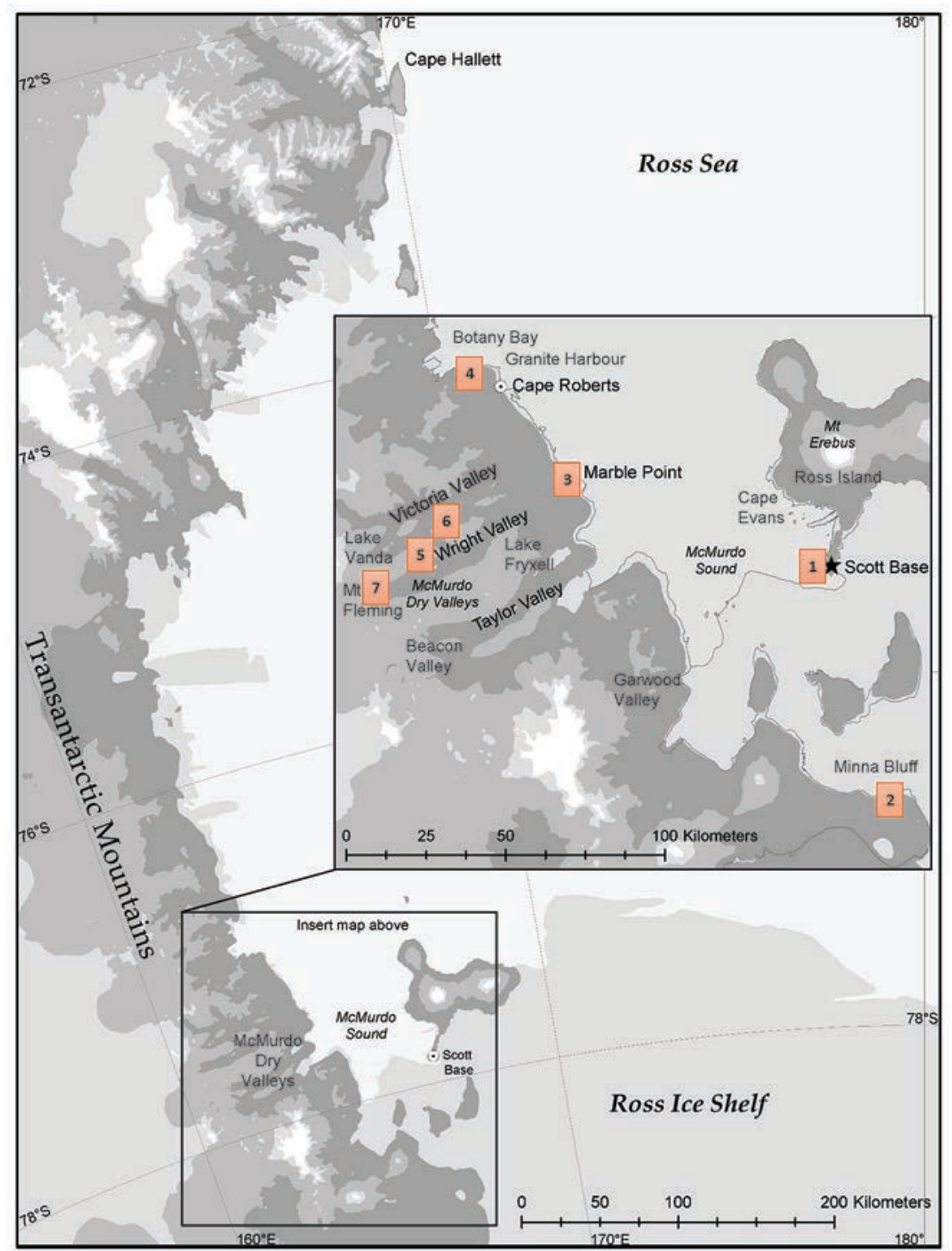

Figure 1. Location of study sites in the Ross Sea Region. Numbers refer to soil climate monitoring stations. $1=$ Scott Base; $2=$ Minna Bluff; $3=$ Marble Point; $4=$ Granite Harbour; $5=$ Wright Valley; 6 = Victoria Valley; 7 = Mount Fleming.

The effect of time on soil development has been studied in the MDVs to determine the relative timing of various glacial advances and retreats. Salt horizon development (Bockheim, 1990), soil colour, the amount of clay present, and the extent of staining, exfoliation, cavernous weathering and ventifaction of surficial materials are distinctive indicators of age difference in many Antarctic soil sequences (Campbell and Claridge, 
1975). Soils are formed in surface materials ranging from Holocene to Pliocene in age (Prentice et al., 1998). However some surfaces may have been buried in ice for long periods leaving very little evidence or impact in the underlying soil materials. The youngest soils are generally found on deposits closest to glaciers and on young features such as beaches, sand dunes, or stream deposits. The oldest, most strongly weathered soils are often found on high, upland surfaces (Campbell and Claridge, 1987; Bockheim, 2010) which have escaped the erosive effects of subsequent glacial fluctuations.

\subsection{Soil Composition}

Most MDV soils have a desert pavement surface which comprises gravels and stones. The desert pavement forms as finer materials are eroded, primarily by wind, until a protective surface layer of coarser material remains. Mature undisturbed Antarctic desert pavements are typically characterised by a closely packed layer of gravel, cobble, and boulder-sized material, which can be ventifacted, pitted, and coated with desert varnish, depending on age.

The depth to which soils thaw each summer is referred to as the active layer. Beneath the active layer is permafrost, defined as having a temperature of less than $0^{\circ} \mathrm{C}$ for at least two consecutive years (Soil Survey Staff, 2014; Grosse et al., 2011). A transitional layer is increasingly being recognised at the top of the permafrost which occasionally thaws during particularly warm summers (Bockheim, 2015b).

Beneath the desert pavement soil materials are generally loose and unconsolidated and soil texture ranges from sand grains in bedrock cracks and joints, through bouldery gravelly sands, to soils with a sandy loam texture. Soils with silt and clay dominant textures occur occasionally where the soil has formed from a fine grained material such as lake-bed sediment.

The soil mineralogy is generally similar to that of the parent rock materials as a result of the dominance of physical weathering and restricted chemical weathering due to cold temperatures and lack of liquid moisture. Where physical processes have reduced particle sizes of mineral materials the opportunities for chemical weathering are increased and a range of secondary clay minerals occur, though they rarely make up more than $1 \%$ of the soil.

Like other desert soils, where evaporation exceeds precipitation, salts accumulate; in general the older the soil the greater the salt accumulation. Salts may occur as encrustations on rocks or as efflorescences on the soil surface. The salts are sometimes dispersed throughout the soil or they may be concentrated in discrete horizons or lenses. The salts consist largely of chlorides, nitrates and sulphates of sodium, potassium, calcium and magnesium (Campbell and Claridge, 1987). Calcite often forms on the underside of stones (Claridge, 1965; McCraw, 1967) and gypsum crusts may be found on old surfaces at high altitudes.

Because of the low clay and organic matter contents the soils have a low $\mathrm{pH}$ buffering capacity. Therefore the salts that accumulate have a strong effect on soil $\mathrm{pH}$. Soil $\mathrm{pH}$ ranges from about $\mathrm{pH} 6$ to $\mathrm{pH} 9$ (Campbell and Claridge, 1987; Aislabie et al., 2008; Bockheim and McLeod, 2015) with a tendency for higher $\mathrm{pH}$ closer to the sea (reflecting a marine origin for some of the salts) (Campbell et al., 1998b). 
Soil colour in the MDVs reflects both parent material and age of the surface (and degree of oxidation). Most MDV soils lack the distinct horizon development of soil profiles in temperate regions.

\subsection{Soil and permafrost temperatures and active layer depth}

For much of the year soils in Antarctica are at temperatures below $0^{\circ} \mathrm{C}$ (Fig. 2). However, over the summer months (December-January) when sunshine is incident for 24 hours per day the soils are warmed at the surface. The surface soil absorbs radiant energy and soil surface temperatures often become higher (sometimes $>15^{\circ} \mathrm{C}$ ) than the ambient air temperatures which generally remain near or below $0^{\circ} \mathrm{C}$. Heat is conducted downwards thawing the near-surface soil (Fig. 2).
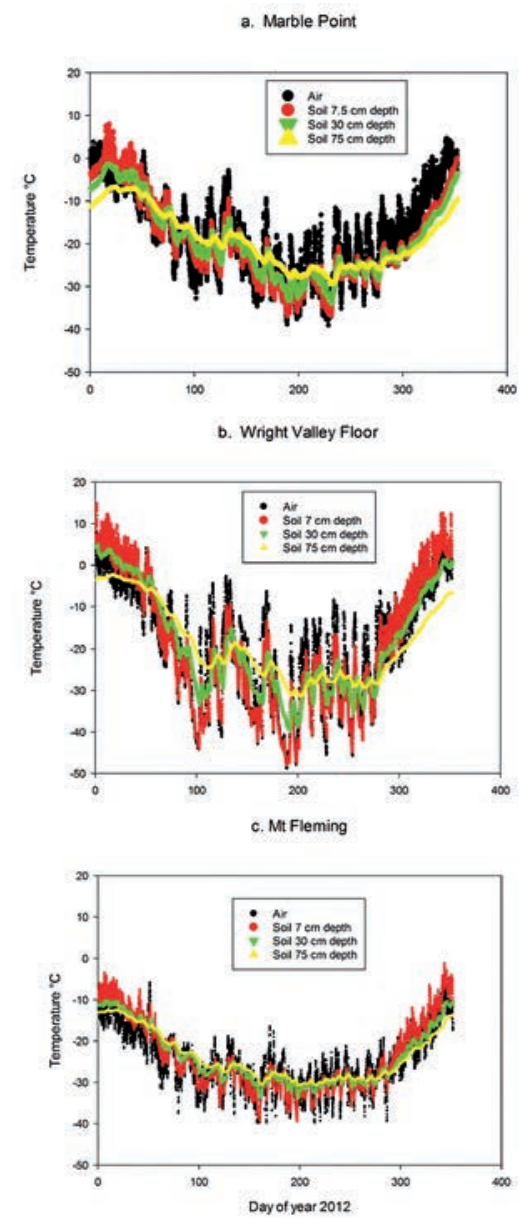

Figure 2. Soil temperatures recorded at $7.5 \mathrm{~cm}$ depth, $30 \mathrm{~cm}$ depth, and $75 \mathrm{~cm}$ depth at Ross Sea Region climate stations. a. Marble Point, $b$. the Wright Valley floor at the foot of Bull Pass, $c$. Mt Fleming at the head of the Wright Valley (Locations are marked on Figure 1). 
The maximum depth of thaw has an important impact on many soil properties and generally varies with both latitude and altitude (Campbell et al., 1998b; Adlam et al., 2010). The mean active layer depth varies both spatially and temporally (Table 1) with marked between-season variability (Adlam et al., 2010) as illustrated by the standard deviations in Table 1. The maximum depth of thaw is greater in moist soils, such as on lake margins, as thermal conductivity of moist soil is greater than dry soil (Ikard et al., 2009; Gooseff et al., 2013).

Table 1. Summary of active layer depths for seven sites in the McMurdo Dry Valleys region (Collated from Adlam et al. 2010, Goddard et al. 2012). Locations of the soil climate monitoring stations are shown in Figure 1.

\begin{tabular}{|l|c|c|c|c|c|}
\hline \multicolumn{1}{|c|}{ Site name } & $\begin{array}{c}\text { Years of } \\
\text { record }\end{array}$ & $\begin{array}{c}\text { Latitude } \\
\text { Degrees } \\
\text { South }\end{array}$ & $\begin{array}{c}\text { Altitude } \\
(\mathbf{m})\end{array}$ & $\begin{array}{c}\text { Mean depth } \\
\text { of active layer } \\
(\mathbf{c m})\end{array}$ & $\begin{array}{c}\text { Standard } \\
\text { deviation } \\
(\mathbf{c m})\end{array}$ \\
\hline Scott Base & '99-'07 & 77.5 & 51 & 32 & 6 \\
\hline Minna Bluff & ${ }^{\prime} 04-' 06$ & 78.3 & 28 & 22 & 4 \\
\hline Marble Point & '99-'07 & 77.3 & 55 & 49 & 9 \\
\hline Granite Harbour & '04-'07 & 77.0 & 6 & $>90$ & - \\
\hline Wright Valley & '99-'07 & 77.3 & 155 & 46 & 7 \\
\hline Victoria Valley & '99-'07 & 77.2 & 408 & 21 & 4 \\
\hline Mt Fleming & '03-'07 & 77.3 & 1670 & 6 & 2 \\
\hline
\end{tabular}

Topographic positon and soil surface albedo also impact on the soil thermal regime with lower soil temperatures on higher albedo soils (Campbell et al., 1997; Balks et al., 2002). Soil surface albedo is markedly lower (6-10\%) on soils formed on darker parent materials such as basalts and dolerites than on paler sandstone, granite, or marble dominated surfaces (21-26\%) (Campbell et al., 1997; Balks et al. 2002).

Even in summer with daylight $24 \mathrm{hrs} /$ day there is diurnal temperature variation due to the lower angles of incidence of the sun at "night", and intermittent shading from adjacent hills in many places which impacts the incoming solar radiation (Dana et al., 1998). For a small part of the year (up to two months at some sites) soil surface temperatures are above $0^{\circ} \mathrm{C}$ for extended periods, providing some opportunity for liquid moisture and biological activity. Goddard (2013) reported that the mean cumulative days per summer with temperatures greater than $0^{\circ} \mathrm{C}$ for soils at $5 \mathrm{~cm}$ depth ranged from 70 days on the floor of the Wright Valley and a north-facing edge of Granite Harbour to 56 days at Marble Point, 50 days on the floor of Victoria Valley and 0 days on the slopes of Mt Fleming. Within the MDVs the maximum depth of thaw is generally reached in mid-January, however there is some inter-annual variability, for example maximum summer thaw was recorded on 9 December 2006 at Mt Fleming, and on 31 January 2007 at Scott Base (Adlam et al., 2010).

Permafrost temperatures in bedrock have been monitored on the floor of the Wright Valley and at Marble Point. Guglielmin et al. (2011) reported that in 2008 the annual permafrost temperature fluctuations were less than $0.1^{\circ} \mathrm{C}$ at a depth of $27 \mathrm{~m}$ with a temperature of $-19.1{ }^{\circ} \mathrm{C}$ in the Wright Valley, and at $25 \mathrm{~m}$ depth with a temperature of $-17.2^{\circ} \mathrm{C}$ at Marble Point. In contrast to the stable temperatures of permafrost at depth, 
the bedrock temperatures at $0.6 \mathrm{~m}$ depth ranged from +1.0 to $-37.9^{\circ} \mathrm{C}$ in the Wright Valley and +1.3 to $-36.2^{\circ} \mathrm{C}$ at Marble Point over one year. The near-surface maximum temperatures were a little higher in the bedrock boreholes than in adjacent till, reflecting the higher thermal conductivity of the rock. Guglielmin et al. (2011) calculated the total depth of permafrost to be about $680 \mathrm{~m}$ at Wright Valley and $490 \mathrm{~m}$ at Marble Point.

\subsection{Soil moisture content}

Active layer soil moisture contents are generally low (Fig. 3). Ten years of monitoring soil moisture contents at 7 sites in the Ross Sea Region (Seybold et al., 2010) showed that mean volumetric liquid soil moisture contents ranged from about $1 \%$ in near-surface soil in the McMurdo Dry Valleys to about 20-30\% near the icecemented permafrost interface at some coastal sites. The coastal sites generally had 3-4 moistening events per summer that extended to at least $20 \mathrm{~cm}$ depth. However in the 10 year record no moistening events extended to $20 \mathrm{~cm}$ depth at the site on the floor of the Wright Valley. Thus in many Antarctic soils moisture availability is a major limitation to development of plant or microbial communities (Kennedy, 1993).
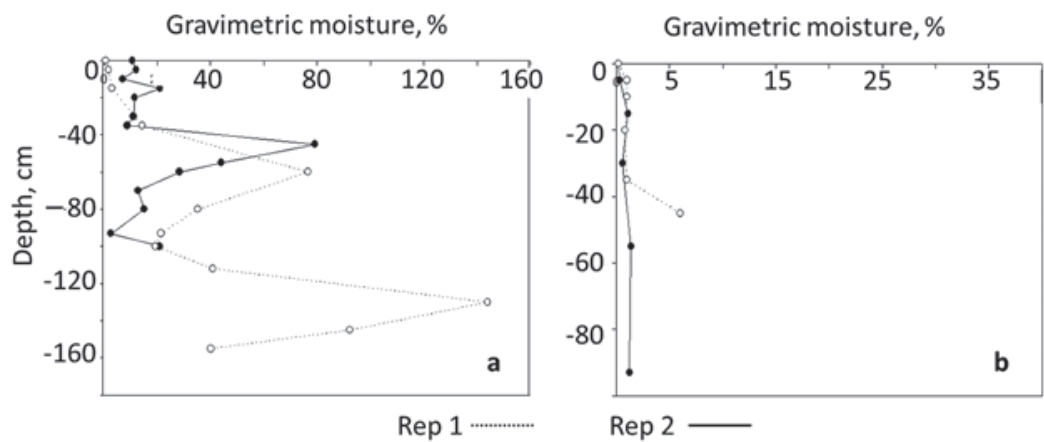

Figure 3. Examples of soil and permafrost gravimetric moisture contents from soils at a. moist coastal and b. dry inland sites. Gravimetric water content is the mass of water per mass of dry soil. The depth to permafrost is about $40 \mathrm{~cm}$ at these sites. The solid and dotted lines distinguish two different sites (after Campbell et al., 1998b).

Along coastal margins where there is seasonal snow-fall the soils may be moistened during snow-melt. In many areas the soil moistening effect is brief as it takes about two weeks for the near-surface $(0-10 \mathrm{~cm}$ depth) soil to dry from saturated, back to less than $5 \%$ moisture (Campbell et al., 1998a). Because of the low humidity a large portion of the snow is lost directly to the atmosphere by sublimation, and thus the water is never available to the soil.

Soils are also moistened by capillary rise on the margins of lakes and streams and through water tracks where moisture moves down-slope, often along long-established tracks, beneath the soil surface. Water tracks become evident as dark lines on the soil surface as a result of the higher soil moisture. Soil moistening from capillary rise was observed to extend to about $7 \mathrm{~m}$ outwards from Lake Vanda in the Wright Valley 
(Campbell et al., 1998a) and about $14 \mathrm{~m}$ from Lake Fryxell in the Taylor Valley (Ikard et al., 2009) (Fig. 1). Shanhun (2005) reported the wetted area adjacent to the Goodspeed stream in the Wright Valley extended up to $74 \mathrm{~m}$ from the stream with some moisture travelling down the alluvial fan as subsurface (water track) flow, rather than just as a result of capillarity. The outer margins of hyporheic zones and water tracks are often quite salty as salt accumulates where the water is evaporating at the edge of the moistened zone. Gooseff et al. (2013) describe water tracks as "solute superhighways" as they move both salt and water downslope relatively rapidly.

There are areas where runoff from snow or glacier melt occurs for a large portion of the summer months. Here the soil will be saturated and ephemeral streams form. For example the soil on the foot-slope on the edge of Granite Harbour at and near Botany Bay (Fig. 1) has moisture flowing through it for a large portion of the summer. The water conducts heat into the soil providing an unusually deep (>90 cm, Table 1) active layer at the site (Adlam et al., 2010). Gooseff et al. (2013) reported saturated conditions in snowinfluenced soils in the Wright and Taylor Valleys for half of the 2009/10 summer and about $4 \%$ gravimetric moisture within $30 \mathrm{~m}$ of snow packs (compared to non-meltwater influenced gravimetric moisture contents of about 1\%). They also noted greater depths to ice cement in the moist soils than adjacent drier soils.

\subsection{Permafrost}

Permafrost within soil materials can be classified into three broad types as a function of soil moisture content, namely: ice-cemented permafrost, dry permafrost, and ice-cored moraine (Fig. 4). Where there is enough water in the permafrost (usually more than about $10 \%$ ) then the permafrost will be ice-cemented (and difficult to sample except by drilling). Outside the period of maximum thaw (such as in November and December) the active layer may also be frozen and ice-cemented, thus the presence of ice-cement does not always infer permafrost.

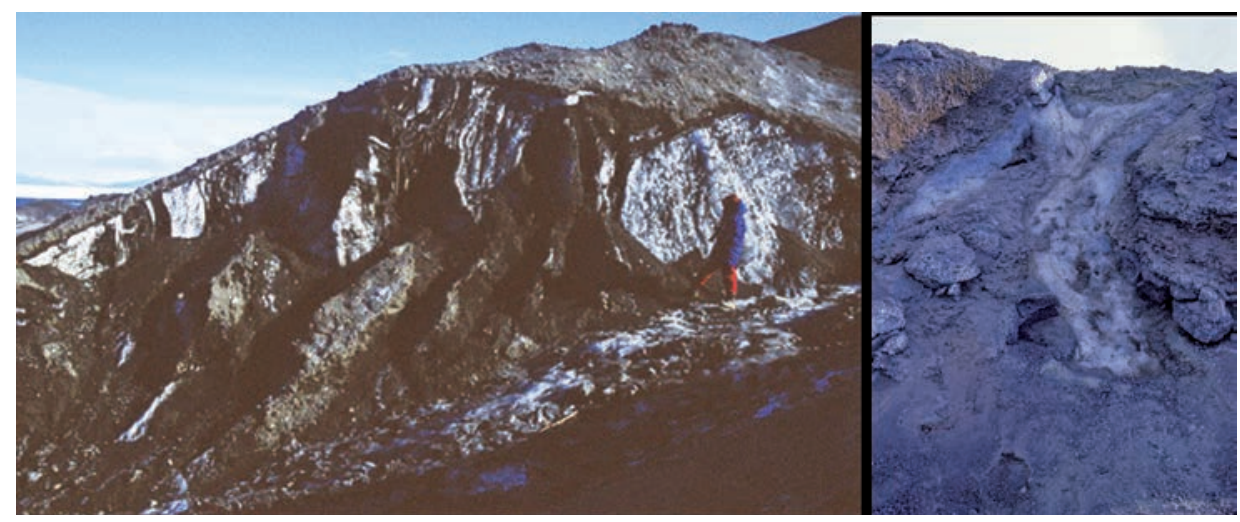

Figure 4. Exposed permafrost ice. Left: Soil profile at McMurdo Station in 1990 with the active layer clearly discernible at the ground surface and the underlying permafrost exposed by rapid stream erosion to reveal ice-cored moraine (note person for scale). Right: Ice wedge in patterned ground crack exposed in a road excavation near Scott Base, C1990. Height of section approx. $4 \mathrm{~m}$. 
Lenses or wedges of ice may occur within ice-cemented permafrost. There is often an ice-rich layer at the top of the permafrost (Fig. 3) where moisture condensates and then freezes at the permafrost interface. Ice wedges are most often formed in patterned ground cracks. Where large ice lenses or wedges occur, moisture contents may range up to $100 \%$ moisture by volume (or $>>100 \%$ gravimetric moisture, e.g. Fig. 3).

In dry environments on some older high altitude surfaces, such as the "Dias" in the Wright Valley, and at some sites within the mid-sections of the dry valley floors, there is not enough water present in the soil to form ice-cement in the permafrost. Thus the permafrost remains loose and easily excavated and is referred to as "dry permafrost. To distinguish between the active layer and underlying dry permafrost, temperature monitoring needs to be undertaken to determine both the time and depth of maximum thaw. The presence or absence of ice-cement at temperatures below $0^{\circ} \mathrm{C}$ is also influenced by the salinity of the soil (Campbell et al., 1997, 1998a) with saltier soils needing higher water contents and temperatures below $0^{\circ} \mathrm{C}$ to form ice-cement.

Ice-cored moraine occurs where glacial ice remains beneath the soil surface (Pewe 1960; Bockheim et al., 2007). The overlying soil forms in "ablation till" which is the mineral material that has been carried within the glacier and left behind at the surface as the glacier ice has gradually ablated. Eventually the surface till layer becomes thick enough to largely insulate the underlying ice from further ablation. Thus the ice-core becomes relatively stable and the overlying soil gradually becomes strongly developed. Ice-cored moraine, such as that in the Beacon Valley (Fig. 1), is often characterised by large-scale, high-centred, patterned ground polygons. Bockheim et al. (2007) estimated that $43 \%$ of MDV surfaces comprise dry permafrost, $55 \%$ have ice-cemented permafrost and about $2 \%$ are ice-cored moraine.

\subsection{Soil organisms}

In the MDVs there is little visible evidence of soil organisms and no vascular plants. However, despite the hostile environment soil biological communities exist that include collembola and mites, (McGaughran et al., 2008), and nematodes (Freckman and Virginia, 1997; Adams et al., 2007). Where conditions are favourable, algal crusts, lichen communities (on rock surfaces protected from the wind), and endolithic communities (occurring under rocks or in rock fissures), have been reported. The tardigrades, rotifers, protists, fungi, and prokaryotes are less studied, but potentially the most diverse groups (Adams et al., 2006). MDV soils can harbour bacterial numbers of up to 109 cells g-1 dry soil (Aislabie et al., 2008, Cannone et al., 2008). Recent molecular genetic studies show high levels of microbial diversity. For example, Lee et al. (2012) investigated soils from four geographically disparate Dry Valleys and reported that the four communities were structurally and phylogenetically distinct, with varying levels of diversity.

Soil pH, salinity, and available water content, can impact the abundance, community structure, and ecosystem functioning of Antarctic biological systems (Cameron et al., 1970; Kennedy, 1993; Freckman and Virginia, 1997; Billi and 
Potts, 2002; Saul et al., 2005; Nkem et al., 2006; Smith et al., 2006; Aislabie et al., 2006a, 2006b, 2008; Chong et al. 2009, 2012; O'Neill et al., 2013b, 2015). High spatial variability in abiotic factors, such as water content, can result in high variability in species diversity and community structure (Niederberger et al., 2008; Smith et al., 2010).

Because of the coarse texture of MDV soils the soil moisture holding capacity is low. However, even at low soil moisture contents much of the water may not be strongly held in the soil (due to the generally low $(<<1 \%)$ clay and organic matter content) so it may be possible for micro-organisms to operate at lower moisture contents than would generally be expected.

In coastal areas penguin rookeries provide a major impact on soils in localised areas forming ornithogenic soils (e.g. Hofstee et al., 2006).

\section{Results: Incidences of active fan-building and erosion events}

We have observed two active fan-building events, one at Cape Evans (Fig. 1) in early January 2009 (Fig. 5), and one in the Wright Valley north wall near the eastern end of Lake Vanda (Fig. 1) which we observed at the end of December 2009 (Fig. 6). It was evident that the Cape Evans event had occurred in the weeks immediately prior to our visit and the Wright Valley event had most likely occurred in the summer prior to our visit (2008/09), possibly about the same time as the Cape Evans event.

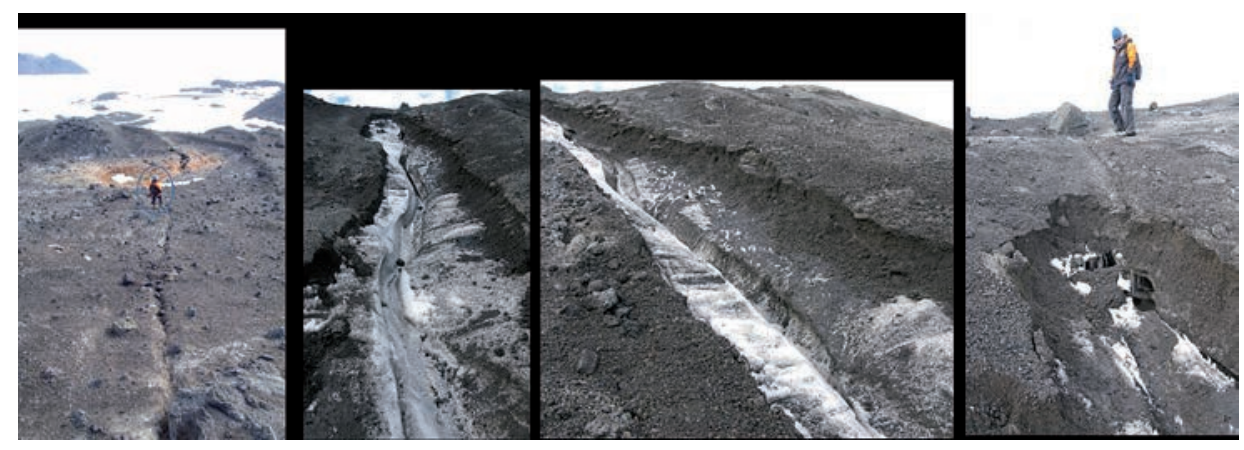

Figure 5. An active gully-forming event at Cape Evans in January 2009. Left: drained lake that was the source of water (person for scale standing on the former lake margin). A patterned ground crack intersects the former lake. Centre left and centre right: gully formed by water erosion - note exposed surface soil over ice cored moraine. Right: head of eroded gully on outer edge of the moraine where water emerged, having moved beneath the ground surface from the lake that is uphill beyond the person.

The Cape Evans event serves as an example of the process that may occur. A small lake, one of several situated on a hummocky ice-cored moraine (at $77^{\circ} 38^{\prime} 16.2^{\prime \prime} \mathrm{S}, 166^{\circ} 26^{\prime}$ 38.4" E) was underlain by a patterned ground crack (Fig. 5). The water in the lake thawed 
and conducted heat and moisture into the underlying soil until it came in contact with the ice in the underlying patterned ground ice-wedge. The contact between the lake water and the ice-wedge caused the ice-wedge to melt, allowing the water to move about 15 $m$ along the subsurface within the patterned ground crack until it emerged at the ground surface on the outer edge of the moraine. The extent of the gully erosion (that formed a straight gully about $40 \mathrm{~m}$ long and about $1 \mathrm{~m}$ deep), and deposition of material at the foot of the slope, suggests that this was a rapid event with all the water draining from the lake over a short time period once it broke through the moraine. The water from the drained lake would have also been added to by meltwater from the ice that it cut through. Once the ground-ice was exposed at the surface it continued to melt and ablate with the soil material from the sides of the gully slumping in. Gradually an insulating layer of soil material would be expected to accumulate on the surface, insulating the underlying ice from further melt-out and leaving only a gravel-covered gully visible. It is evident in more recent photos on Google Earth that the gully captures blowing snow. Periodic snow melt and water erosion could be expected to continue the gradual process of melting of underlying ice and enlargement of the gully.

There are many fans visible on the walls of the Wright Valley, and it is often assumed that they are stable relict features. However in December 2009 we observed clear evidence for a fan-building event that we consider most likely occurred in the 2008/09 summer (Fig. 6). The material was deposited across a former trial site that was established in 1993/94 summer (Campbell et al., 1998c) (at 77³1'10.0” S, 161 40'43.4” E). The fanbuilding event had not occurred when the site was revisited in the 2000/01 summer. The transported materials were dried and stabilised so had not been deposited immediately prior to our visit. However they appeared "fresh" with no evidence of wind erosion, thus our conclusion that they were most likely deposited in the previous summer. In contrast to the Cape Evans event the Wright Valley fan was a much larger scale, on a site that had evidence of numerous similar previous events. The feature was divided into seven zones (Table 2) covering a total horizontal distance of about $3 \mathrm{~km}$ and an altitudinal range of about $1400 \mathrm{~m}$. The moisture source was the snow accumulation zone above about $1100 \mathrm{~m}$ altitude (Fig. 6). The snowmelt event must have led to a reasonably concentrated water flow but it was likely to have been sustained for a longer period than that observed at Cape Evans as there was a much larger potential source area and the distributary channels in the lower part of the fan suggest stream flow that may have been sustained for hours or days. The flow was initially concentrated in a narrow gully which is snowfilled in the photos in Fig. 6, but is not perennial snow as evidenced in some photos on Google Earth. The flow changed from an erosive to depositional event as the slope dropped below about $13^{\circ}$ and the number of distributary channels would have led to less intense flow in any one channel. The evidence of deposited material declined as the slope dropped below about $6^{\circ}$. 
Table 2. Altitudes, distances, and slopes of zones within Wright Valley active fan event (altitude and distance data derived from Google Earth).

\begin{tabular}{|l|c|c|c|c|}
\hline \multicolumn{1}{|c|}{ Zone } & $\begin{array}{c}\text { Altitude at top } \\
\text { of zone (m) }\end{array}$ & $\begin{array}{c}\text { Altitude at } \\
\text { base } \\
\text { of zone (m) }\end{array}$ & $\begin{array}{c}\text { Horizontal } \\
\text { distance } \\
(\mathbf{m})\end{array}$ & $\begin{array}{c}\text { Slope } \\
\text { (degrees) }\end{array}$ \\
\hline Snow accumulation zone & 1500 & 1100 & 980 & 22 \\
\hline Transition snow-gut & 1100 & 635 & 769 & 31 \\
\hline Upper distributary eroded zone & 635 & 278 & 758 & 25 \\
\hline Mid-slope eroded zone & 278 & 219 & 217 & 15 \\
\hline Lower eroded zone & 219 & 178 & 173 & 13 \\
\hline Deposition zone & 178 & 134 & 226 & 11 \\
\hline Runout zone & 134 & 120 & 138 & 6 \\
\hline
\end{tabular}

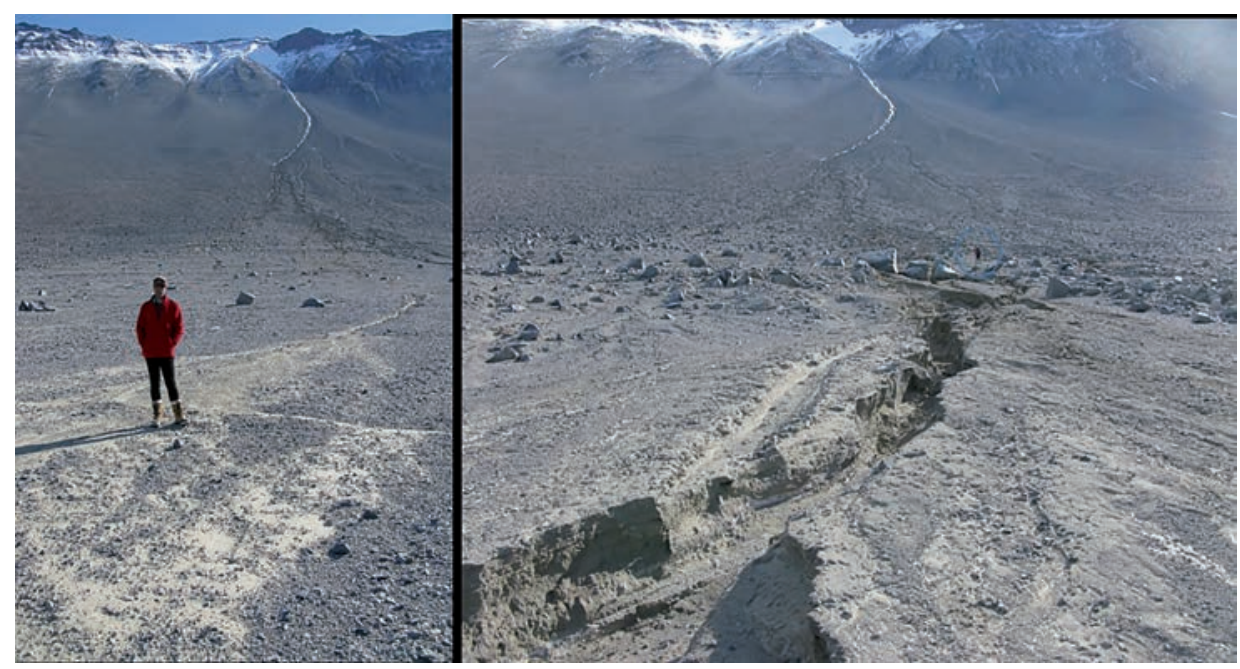

Figure 6. Gully erosion and fan deposition on the north wall of Wright Valley, observed in December 2009. Left: fine sandy silt material deposited on the lower less steep slopes (deposition zone), arrived as a fine slurry that did not erode the underlying surface. Right: recent gully erosion has cut through similar previous deposits in the lower eroded zone. Note a person for scale near the bottom of the mid-slope erosion zone, and extensive new gully erosion further up the face in the upper eroded zone.

\section{Discussion}

\subsection{Stable vs dynamic landscapes}

The MDV landscape has been considered stable over periods extending to millions of years (Denton et al., 1993; Marchant and Head, 2007) particularly at higher altitudes where soil temperatures remain below $0^{\circ} \mathrm{C}$ slowing weathering and geomorphic processes. 
The two examples of erosion events shown here illustrate occasional events that occur within the MDVs. Evidence of previous gully-erosion and deposition on valley walls show that these are not unique events. Such occasional events, attributed to warmer than average summers, were described by Chinn (1979). A warm summer with air temperature of $15^{\circ} \mathrm{C}$ recorded at Lake Vanda in January 1974 resulted in extensive melting and water flow in the MDVs (Chinn, 1979). A number of small lakes formed in formerly dry depressions, one of which Chinn (1979) estimated would take 25 years to evaporate. Chinn (1979) also reports an exceptionally high snowfall event in 1977, which led to minimal flow in the Onyx River for two seasons, and variations of an order of magnitude in the flow of the Onyx River between seasons in the early 1970s. As Chinn (1979) observed, rare "extreme" events in the MDVs can have lasting impacts on the landscape. The 2000/01 summer was notably warmer than average in the MDVs (Barrett et al., 2008; Adlam et al., 2010) resulting in deeper than average penetration of the active layer at sites across the region and high meltwater flows with flooding and stream-bank erosion on the Onyx River and other streams. The pulse of meltwater impacted ecosystems in the Taylor Valley for several years afterwards (Barrett et al., 2008).

Fountain et al. (2014) describe increased occurrence of stream erosion and stream incision associated with erosion of surface soil material, and subsequent melting of underlying massive ice, over the previous decade in the Lower Wright, Taylor and Garwood Valleys which they found correlated with an increase in incoming solar radiation though no change in summer air temperatures.

\subsection{Impacts of possible future natural or human-induced changes to the physical soil- permafrost environment}

Fountain et al. (2014) identified low elevation and relatively warm coastal zones as most prone to changes as a result of warming events. These could potentially be areas of future melting of buried ice and likely landscape changes including changes in stream courses, and new patterns of erosion, and deposition.

Future changes to the soil-permafrost environment have potential to occur in response to warming, be it an "occasional event" or prolonged global climate change, and thus deepening of the active layer. Human activities that impact on the thickness and stability of the active layer can also invoke similar impacts. The physical response to changes in the soil thermal regime depend largely on the form of the underlying permafrost, the severity of the disturbance (from the "norm"), and the climate regime of the site in question.

The high altitude areas that have demonstrably been stable for millions of years through many past climate fluctuations are likely to remain relatively un-impacted, though there is potential for them to be buried by snow for long periods with minimal impact on the underlying soils.

Dry permafrost soils would not be expected to change greatly as a result of a warming or disturbance event as the underlying permafrost has insufficient moisture to 
cause any melting or other effects. In soils with ice-cemented permafrost the removal or deepening of the active layer would lead to changes in the underlying permafrost. Where there is an ice-rich layer at the top of the permafrost, or within ice wedges, there will be an initial melting event and most of the moisture is likely to subsequently be evaporated from the soil. Campbell et al. (1994) showed that about 40 years after removal of the active layer in soils at Marble Point an ice-rich layer had not reformed at the new permafrost interface. Thus, once the initial melting has occurred (which is likely to be associated with some subsidence of the soil surface), the soils are likely to form a new stable equilibrium with a deeper active layer and without the ice enrichment there is unlikely to be ongoing melting.

As Fountain et al. (2014) suggest, the greatest impacts of warming that deepens the active layer, or disturbance that removes the active layer, will occur where the soil is underlain by massive ground ice. Ongoing melting and surface slumping will occur until sufficient mineral material has accumulated at the ice surface to insulate the underlying ice from further melting or ablation. Such effects can be easily observed in the proximity of McMurdo Station where, particularly during the 1980s and 1990s active layer soil material was regularly removed for road-fill from surfaces underlain by massive ice (as illustrated in Fig. 4) resulting in extensive ice melt-out, soil surface slumping and salt accumulation on the soil surface (Campbell and Claridge, 1987, Fig. 7).

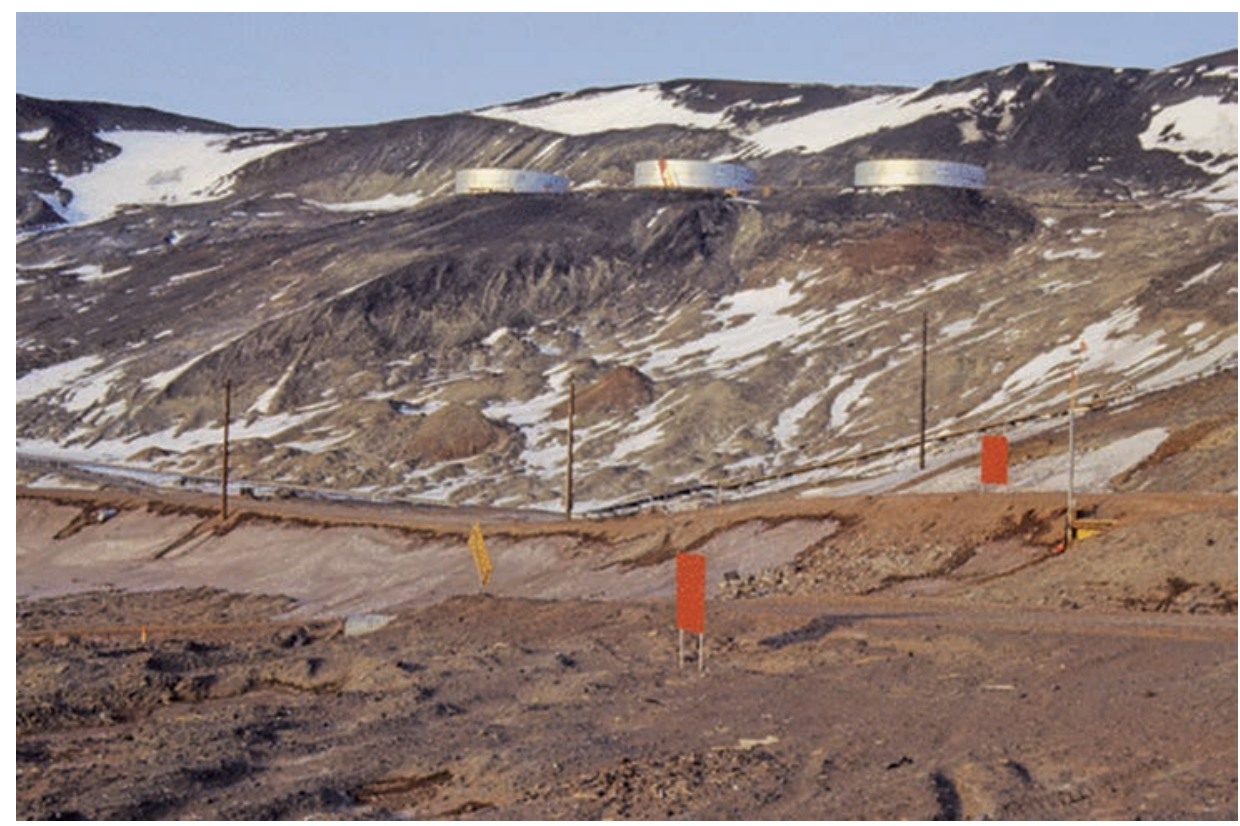

Figure 7. Hummocky topography formed as a result of subsurface ice melt-out following active layer removal at McMurdo Station in the early 1990s. The fuel tanks were subsequently removed to a more stable location. 
Low elevation and relatively warm coastal zones are most prone to changes as a result of warming events. Impacts of warming-induced increased melting of glaciers, snow patches, and melting of subsurface ice may potentially include changes in ecological habitats and microbial, moss, and lichen communities. However, given that the mean annual temperatures in the Ross Sea Region, and thus the permafrost temperatures, are in the range of $-17^{\circ} \mathrm{C}$ to $-24^{\circ} \mathrm{C}$, other than some deepening of the active layer, and resulting ice-melt as the depth to permafrost adjusts, major changes in permafrost regimes are unlikely to occur in the foreseeable future.

\section{Conclusions}

Evidence suggests that the landscapes in the Ross Sea Region are more dynamic than some researchers have assumed. The region has experienced short-lived erosion and depositional events resulting from warmer than average summers, higher than average snowfall, or human disturbances, which lead to melting of sub-surface ice. Such disturbances were documented by workers in the 1970s, observed in the 1990s, and again now in the early 21 st century. The Cape Evans gully erosion event and Wright Valley fanbuilding event reported here are examples of active, rapid, landscape processes occurring occasionally in the Ross Sea Region. Much in the geomorphic record suggests other similar events have occurred repeatedly in the past.

Future changes to the soil-permafrost environment have potential to occur in response to human disturbance or to warming, be it an "occasional event" or prolonged global climate change. Responses to changes in the soil thermal regime depend largely on the form of the underlying permafrost, the severity of the disturbance, and the climate regime of the site.

The high altitude areas that have demonstrably been stable for millions of years through many past climate fluctuations are likely to remain relatively unchanged. Dry permafrost soils would not be expected to change greatly as a result of a warming or disturbance event as the underlying permafrost has insufficient moisture to cause any melting or other effects. In soils with ice-cemented permafrost the removal or deepening of the active layer would lead to changes in the underlying permafrost. Where there is an ice-rich layer at the top of the permafrost, or within ice wedges, there will be an initial melting event and most of the moisture is likely to subsequently be evaporated from the soil and the soils are likely to form a new stable equilibrium with a deeper active layer.

The greatest impacts of warming that deepens the active layer, or disturbance that removes the active layer, will occur where the soil is formed in ice-cored moraine and underlain by massive ground ice, particularly in warmer, wetter, coastal areas. Here melting and surface slumping will occur until sufficient mineral material has accumulated at the ice surface to insulate the underlying ice from further melting or ablation.

\section{Acknowledgements}

The work that made this paper possible was largely funded by the New Zealand Foundation of Research, Science and Technology. Antarctica New Zealand provided 
logistic support, and particular thanks to Rob McPhail for helicopter operations. Thanks to the many colleagues who we have worked with in Antarctica over the years, especially: Jackie Aislabie and Malcolm McLeod from Landcare Research; Cathy Seybold, Don Huffman, Deb Harms, and Ron Paetzold from NRCS, USDA; Mauro Guglielmin, Fabio Baio, and Nicoletta Canone from the Italian Antarctic programme; Jerónimo López-Martínez and Enrique Serrano from Spain; Dave Campbell, University of Waikato, Janine Ryburn, Dean Sandwell, and Craig Burgess for technical support; students including Holly Goddard, Leah Adlam, Fiona Shanhun, Aaron Wall, David Holmes, and Erica Hofstee; and mentors Graeme Claridge, Iain Campbell, James Bockheim, and John Kimble.

\section{References}

Adams, B., Bardgett, R., Ayres, E., Wall, D., Aislabie, J., Bamforth, S., Bargagli, R., Cary, C., Cavacini, P., Connell, L., Convey, P., Fell, J.W., Frati, F., Hogg, I.D., Newsham, K.K., O'Donnell, A., Russell, N., Seppelt, R.D., Stevens, M.I. 2006. Diversity and distribution of Victoria Land biota. Soil Biology and Biochemistry 38 (10), 3003-3018.

Adams, B., Wall, D., Gozel, U., Dillman, C., Hogg, I. 2007. The southernmost worm, Scottnema lindsayae (Nematoda): diversity, dispersal and ecological stability. Polar Biology 30, 809815.

Adlam, L.S., Balks, M.R., Seybold, C.A., Campbell, D.I. 2010. Temporal and spatial variation in active layer depth in the McMurdo Sound Region, Antarctica. Antarctic Science 22 (1), 45 52. Doi: 10.1017/S0954102009990460.

Aislabie, J.M., Chhour, K.L., Saul, D.J., Miyauchi, S., Ayton, J., Paetzold, R.F., Balks, M.R. 2006 a. Dominant bacteria in soils of Marble Point and Wright Valley, Victoria Land, Antarctica. Soil Biology and Biochemistry 38, 3041-3056.

Aislabie, J.M., Saul, D.J., Foght, J.M. 2006b. Bioremediation of hydrocarbon-contaminated polar soils. Extremophiles 10, 171-179.

Aislabie, J.M., Duggan, S., Barker, G.M. 2008. Relation between soil classification and bacterial diversity in soils of the Ross Sea region, Antarctica. Geoderma 144, 9-20.

Balks, M.R., López-Martínez, J., Goryachkin, S., Mergelov, N.S., Schaefer, C.E.G.R., Simas, F.N.B., Almond, P.C., Claridge, G.G.C., McLeod, M., Scarrow, J. 2013. Windows on Antarctic Soil-Landscape Relations across selected regions of Antarctica. Geological Society, London, Special Publications 381, 397-410. Doi: 10.1144/SP381.9.

Balks, M.R., Paetzold, R.F., Kimble, J.M., Aislabie, J., Campbell, I.B. 2002. Effects of hydrocarbon spills on the temperature and moisture regimes of Cryosols in the Ross Sea region, Antarctica. Antarctic Science 14 (4), 319-326.

Barrett, J.E., Virginia, R.A., Wall, D.H., Doran, P.T., Fountain, A.G., Welch, K.A., Lyons, W.B. 2008. Persistent effects of a discrete climate event on a polar desert ecosystem. Global Change Biology 14, 1-13.

Billi, D., Potts, M. 2002. Life and death of dried prokaryotes. Research in Microbiology 153, 7-12.

Bockheim, J.G. 1990. Soil development rates in the Transantarctic Mountains. Geoderma 47, 5977.

Bockheim, J.G. 2010. Evolution of desert pavements and the vesicular layer in soils of the Transantarctic Mountains. Geomorphology 118, 433-443.

Bockheim, J.G. 2015a. Soil-forming factors in Antarctica. In J.G. Bockheim (ed.), The Soils of Antarctica. World Soils Book Series, Springer, Dordrecht, pp. 5-20. Doi: 10.1007978-3-31905497-1_2. 
Bockheim, J.G. 2015b. Cryopedology. Springer, Dordrecht, 177 pp. Doi: 10.1007/978-3-31908485-5.

Bockheim, J.G., Campbell, I.B., McLeod, M. 2007. Permafrost distribution and active layer depths in the McMurdo Dry Valleys, Antarctica. Permafrost and Periglacial Processes 18, 217-227.

Bockheim, J.G., McLeod, M. 2015. Soils of Central Victoria Land, the McMurdo Dry Valleys. In J.G. Bockheim (ed.), The Soils of Antarctica. World Soils Book Series, Springer, Dordrecht, pp. 1-8. Doi: 10.1007978-3-319-05497-1_8.

Cameron, R.E., Devaney, J.R. 1970. Antarctic Soil Algal Crusts: Scanning Electron and Optical Microscope Study. Transactions of the American Microscopical Society 89 (2), 264-273.

Campbell, I.B., Claridge, G.G.C. 1975. Morphology and age relationships of Antarctic soils. Royal Society of New Zealand Bulletin 13, 83-88.

Campbell, I.B., Claridge, G.G.C. 1987. Antarctica: Soils, weathering processes and environment. Developments in Soil Science 16, Elsevier, Oxford, 368 pp.

Campbell, I.B., Balks, M.R., Claridge G.G.C. 1994. The effect of human activities on moisture content of soils and underlying permafrost from the McMurdo Sound Region, Antarctica. Antarctic Science 6 (3), 307-314.

Campbell, I.B., Claridge, G.G.C., Campbell, D.I., Balks, M.R. 1998a. The soil environment of the McMurdo Dry Valleys, Antarctica. In J. Priscu (ed.), Ecosystem dynamics in a polar desert. The McMurdo Dry Valleys, Antarctica. Antarctic Research Series Volume 72, American Geophysical Union, Washington DC, pp. 297-322.

Campbell, I.B., Claridge, G.G.C., Campbell, D.I., Balks, M.R. 1998b. Permafrost properties of the McMurdo Sound-Dry Valley Region of Antarctica. In A.G. Lewkowicz, M. Allard (eds.), Proceedings of the Seventh International Conference on Permafrost. Yellowknife, Canada, pp. 121-126.

Campbell, I.B., Claridge, G.G.C., Balks, M.R. 1998c. Short- and long-term impacts of human disturbances on snow-free surfaces in Antarctica. Polar Record 34 (188), 15-24.

Campbell, D.I., MacCulloch, R.J.L., Campbell, I.B. 1997. Thermal regimes of some soils in the McMurdo Sound Region of Antarctica. In W.B. Lyons, C. Howard-Williams, I. Hawes (eds.), Ecosystems Processes in Antarctic ice-free landscapes. Balkema, Rotterdam, pp. 45-55. ISBN 9054109254.

Cannone, N., Wagner, D., Hubberten, H.W., Guglielmin, M. 2008. Biotic and abiotic factors influencing soil properties across a latitudinal gradient in Victoria Land, Antarctica. Geoderma 144, 50-65.

Chinn, T.J.H. 1979. Impacts of "extreme" events on the Dry Valleys area. New Zealand Antarctic Record, 2 (2), 9-13.

Chong, C.W., Pearce, D.A., Convey, P., Tan, I.K.P. 2012. The identification of environmental parameters which could influence soil bacterial community composition on the Antarctic Peninsula - a statistical approach. Antarctic Science 24, 249-258.

Chong, C.W., Tan, G.Y.A., Wong, R.C.S., Riddle, M.J., Tan, I.K.P. 2009. DGGE fingerprinting of bacteria in soils from eight ecologically different sites around Casey Station, Antarctica. Polar Biology 32, 853-860.

Claridge, G.G.C. 1965. The clay mineralogy and chemistry of some soils from the Ross Dependency, Antarctica. New Zealand Journal of Geology and Geophysics 8, 186-220.

Dana, G.L., Wharton, R.A., Dubayah, R. 1998. Solar Radiation in the McMurdo Dry Valleys, Antarctica. In J. Priscu (ed.), Ecosystem dynamics in a polar desert. The McMurdo Dry Valleys, Antarctica. Antarctic Research Series Volume 72, American Geophysical Union, Washington DC, pp. 39-64. 
Denton, G.H., Sugden, G.E., Marchant, D.R., Hall, B.L., Wilch, T.I. 1993. East Antarctic ice sheet sensitivity to Pliocene climate change from a Dry Valleys perspective. Geografiska Annaler Series A 75, 155-204.

Fountain, A.G., Levy, J.S., Gooseff, M.N., Van Horn, D. 2014. The McMurdo Dry Valleys: A landscape on the threshold of change. Geomorphology 225, 25-35.

Freckman, D.W., Virginia, R.A. 1997. Low diversity Antarctic soil nematode communities: distribution and response to disturbance. Ecology 78, 363-369.

Goddard, H.E. 2013. Investigation of air and soil climate across the latitudinal and altitudinal gradient of the Ross Sea Region. MSc thesis, University of Waikato, $166 \mathrm{pp}$.

Goddard, H.E., Balks, M.R., Seybold, C.A. 2012. Soil temperatures over a latitudinal gradient in the Ross Sea Region of Antarctica: Preliminary results. Proceedings of the Tenth International Conference on Permafrost, Salekard, Russia, Vol. 4/1, Extended Abstracts, pp. 183-184. ISBN 978-5-91128-050-5.

Gooseff, M.N., Barrett, J.E., Levy, J.E. 2013. Shallow groundwater systems in a polar desert, McMurdo Dry Valleys, Antarctica. Hydrogeology Journal 21, 171-183. Doi: 10.1007/ s10040-012-0926-3.

Grosse, G., Romanovsky, V.E., Jorgenson, T., Walter, A.K., Brown, J., Overduin, P.P. 2011. Vulnerability and feedbacks of permafrost to climate change. EOS 92 (9), 73-74.

Guglielmin, M., Balks, M.R., Adlam, L.S., Baio, F. 2011. Permafrost thermal regime from two $30-\mathrm{m}$ deep boreholes in southern Victoria Land, Antarctica. Permafrost and Periglacial Processes 22 (2), 129-139.

Hofstee, E.H., Balks, M.R., Petchey, F., Campbell, D.I. 2006. Soils of Seabee Hook, Cape Hallett, Northern Victoria Land, Antarctica. Antarctic Science 18 (4), 473-486.

Ikard, S.J., Gooseff, M.N., Barrett, J.E., Takacs-Vesbach, C. 2009. Thermal characterisation of active layer across a soil moisture gradient in the McMurdo Dry Valleys, Antarctica. Permafrost and Periglacial Processes 20 (1), 27-39. Doi: 10.1002/ppp.634.

Isaac, M.J., Chinn, T.J., Edbrooke, S.W., Forsyth, P.J. 1996. Geology of the Olympus Range Area of Southern Victoria Land, Antarctica. Institute of Geological and Nuclear Sciences Geological Map 20. Institute of Geological and Nuclear Sciences Ltd, Lower Hutt, 60 pp. ISBN 0-47809513-9.

IUSS Working Group 2014. World Reference Base for Soil Resources 2014. International Soil Classification System for naming soils and creating legends for soil maps. World Soil Resources Reports No. 106, FAO, Rome. ISBN 978-92-5-108369-7.

Kennedy, A.D. 1993. Water as a limiting factor in the Antarctic terrestrial environment - a biogeographical synthesis. Arctic Antarctic Alpine Research 25, 308-315.

Lee, C.K., Barbier, B.A., Bottos, E.M., McDonald, I.R., Cary, S.C. 2012. The Inter-Valley Soil Comparative Survey: the ecology of Dry Valley edaphic microbial communities. The ISME Journal 6, 1046-1057. Doi: 10.1038/ismej.2011.170.

Marchant, D.R., Head, J.W. 2007. Antarctic Dry Valleys; microclimate zonation, variable geomorphic processes, and implications for assessing climate change on Mars. Icarus 192, 187-222.

McCraw, J.D. 1967. Soils of Taylor Dry Valley, Victoria Land, Antarctica, with notes on soils from other localities in Victoria Land. New Zealand Journal of Geology and Geophysics 10 (2), 498-539.

McGaughran, A.B., Hogg, I.D., Stevens, M.I. 2008. Patterns of population genetic structure for springtails and mites in southern Victoria Land, Antarctica. Molecular Phylogenetics and Evolution 46, 606-618. Doi: 10.1016/j.ympev.2007.10.003. 
Niederberger, T., McDonald, I.R., Hacker, A.L., Soo, R.M., Barrett, J.E., Wall, D.H., Cary, S.C. 2008. Microbial community composition in soils of Northern Victoria Land, Antarctica. Environmental Microbiology 10, 1713-1724.

Nkem, J.N., Virginia, R.A., Barrett, J.E., Wall, D.H., Li, G. 2006. Salt tolerance and survival thresholds for two species of Antarctic soil nematodes. Polar Biology 29, 643-651.

O’Neill, T.A., Balks, M.R., Stevenson, B., López-Martínez, J., Aislabie, J., Rhodes, P. 2013b. The short-term effects of surface soil disturbance on soil bacterial community structure at an experimental site near Scott Base, Antarctica. Polar Biology 36 (7), 985-996.

O’Neill, T.A., Aislabie, J., Balks, M.R. 2015. Human impacts on soils. In J.G. Bockheim (ed.), The Soils of Antarctica. World Soils Book Series, Springer, Dordrecht, pp. 281-303. Doi:10.1007978-3-319-05497-1_2.

Péwé, T.L. 1960. Multiple glaciation in the McMurdo Sound region, Antarctica: A progress report. The Journal of Geology, 498-514.

Prentice, M.L., Kleman, J., Stroven, A.P. 1998. The composite glacial erosional landscape of the northern McMurdo Dry Valleys: Implications for Antarctic Tertiary glacial history. In J. Priscu (ed.), Ecosystem dynamics in a polar desert. The McMurdo Dry Valleys, Antarctica. Antarctic Research Series Volume 72, American Geophysical Union, Washington DC, pp. $1-38$.

Saul, D., Aislabie, J., Brown, C., Harris, L., Foght, J.M. 2005. Hydrocarbon contamination changes the bacterial diversity of soil from around Scott Base, Antarctica. FEMS Microbiology Ecology 53, 141-155.

Seybold, C.A., Balks, M.R., Harms, D.S. 2010. Characterization of active layer water contents in the McMurdo Sound region, Antarctica. Antarctic Science 22 (6), 633-645. Doi: 10.1017/ S0954102010000696.

Seybold, C.A., Harms, D.S., Balks, M.R., Aislabie, J., Paetzold, R.F., Kimble, J., Sletten, R. 2009. Soil Climate Monitoring Project in the Ross Island Region of Antarctica. Horizons, Summer 2009, USDA, Lincoln.

Shanhun, F.L. 2005. An Investigation of Soil Moisture Associated with Ephemeral Streams, Wright Valley, Antarctica. MSc Thesis, University of Waikato, New Zealand, $161 \mathrm{pp}$.

Smith, J.J., Ah Tow, L., Stafford, W., Cary, C., Cowan, D.A. 2006. Bacterial Diversity in three different Antarctic cold desert mineral soils. Microbial Ecology 51, 413-421.

Smith, J.L., Barret, J.E., Tusnady, G., Rejto, L., Cary, S.C. 2010. Resolving environmental drivers of microbial community structure in Antarctic soils. Antarctic Science 22 (6), 673-680.

Soil Survey Staff 2014. Keys to Soil Taxonomy. Twelfth Edition. United States Department of Agriculture, Natural Resources Conservaton Service, 360 pp. 